\title{
Religion and Development: Assessing the Contribution of the Faith Based Organizations in Bangladesh
}

\author{
Ayesha Siddika
}

\begin{abstract}
Religion has been playing a significant role in the socio-economic development of the society, more specifically of the under privileged people. Religion or Faith based NGOs are one of the pioneering agents of this kind of development. Though the contributions of such organizations; World Vision or Christian Aid for instances, have been evaluated in the Western academia, in Bangladesh the contributions of these Faith Based Organizations have been overlooked for a long time. FBOs have been working in Bangladesh on diverse issues from poverty reduction to health issues. This article in particular will critically assess the role of the Faith Based Organizations in Bangladesh. Apart from their positive contributions, an attempt has been shown to address few criticisms against them such as conversion and terrorist financing.
\end{abstract}

Key Words: Religion, Development, Faith Based Organizations, Poverty, Health, Education

\section{INTRODUCTION:}

Relationship between religion and development can be understood from two points of view. From one hand religion is an element of development ${ }^{1}$ and on the other, religion is an element of obstruction. This twofold view is very intimate in case of development of Bangladesh. Religion, from a distant past has always been a development issue in Bangladesh. The development of a country depends on varied aspects like income of people, political situation, social stability, justice, good governance and many other things. And religion can be an agent of development. According to Capability Index of Amartya Sen, development must be judged by its impact on people, not only changes in their income but more generally in terms of their choices, capabilities and freedom. ${ }^{2}$ Development, being a holistic thing must not be judged by the traditional economic factors alone. Rather social impactful factors have more to do in this field. There are many religious aid agencies which are working for the development of Bangladesh. They have been contributing in education, relief, child health, poverty reduction, women empowerment, climate change and many other issues ${ }^{3}$. At the same time, many of the Religious Aid Organizations have been accused of patronizing Islamic militants in Bangladesh. Sometimes, these groups have direct relationship with some political parties. As the development of a country largely depend on social and political stability, therefore Religion based conflicts can harm the development of a country. Since 2012, Bangladesh slowly but surely is facing the threat of communal conflicts.

Revised Manuscript Received on January 15, 2021

Ayesha Siddika*, Lecturer, Department of World Religions and Culture, University of Dhaka, Bangladesh.

(C) The Authors. Published by Blue Eyes Intelligence Engineering and Sciences Publication (BEIESP). This is an open access article under the CC BY-NC-ND license (http://creativecommons.org/licenses/by-nc-nd/4.0/)
* Correspondence Author

If the ongoing conflicting situation persists in the name of religion, then the development of our country will also face a crisis. As part of global politics, international extremist groups are making Bangladesh their target.

The present paper is an attempt to explore faith factors in the development of Bangladesh. An endeavor is also shown to understand how faith factors are working in the development of Bangladesh. This research has been conducted by following qualitative research methodology based on secondary data available at books, journals, newspapers and websites.

\section{NGOS BASED ON RELIGIOUS ETHICS AND INTERFAITH HARMONY:}

There are more than one thousand of organizations in Bangladesh which are directly or indirectly linked to working in development sector as NGO. Some of the organizations are in the names of NGO, some of them are charity organization and some of them are political organizations. Their activities are also diversified ranging from propagation of faith to various development activities. Some organizations are not registered as NGO, some organizations have direct political involvement and few banks are associated in this area. WFDD research named 152 faith inspired organizations. ${ }^{2}$ They have used the term FIO inclusively to define organizations that includes organizations who work in development sectors and they are motivated by any religion.. WFDD research has found just 152 registered FIOs in Bangladesh constituting 70 Christian, 60 Muslim, 11 Buddhist, 10 Hindu and 1 multi faith inspired organizations. Many of them started working after 1971 and 1991. In 152 organizations, at least 50 organizations are INGO like World Vision, Muslim Aid, Mennonite Central Committee and others which receive funds from international lobby.

Findings of the contributions of the FBOs in the development of Bangladesh

2.1. Poverty Reduction:

Bangladesh has a great contribution in the poverty reduction circle in the recent years. ${ }^{3}$ In 2018, the poverty rate of Bangladesh dropped to around $21 \%{ }^{4}$ The government says the poverty rate is declining while the average life expectancy rate is increasing in Bangladesh which was 31.5\% in $2010^{.5}$ The change was not an overnight phenomenon. Rather the government along with private organizations had to work a lot in this field. That is why, in achieving MDGs goals, Bangladesh became a role model for the other developing countries. The significant increase of Labor income boost of garments sectors, reduction of fertility rate, different government and NGO programs are the main causes for the significant reduction of poverty in Bangladesh.

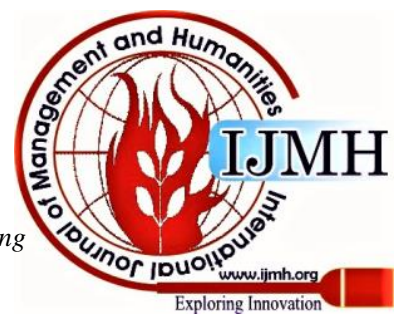


In spite of progress in this sector, the poverty rate is still high and a lot of work to be done yet.

Islamic Relief Bangladesh (1994), a local NGO of Islamic Relief Worldwide (founded in UK in 1984 in response to the famine of Sudan and Ethiopia) are working to reduce poverty in Bangladesh. Their principal focuses on food security and Income Generating activities ( IGAs). The uniqueness of this organization is its attitude of payoff. They really don't depend on "Return Strategy". 6 And this group does not follow general micro-financing system. They are opposed to any interest. Their target people are women, families having no breadwinner, people suffering from chronic diseases etc. The current strategy of IRB is termed as "Asset Transfer Model" meaning providing microfinance to buy an asset. ${ }^{7}$ The beneficiaries are divided into small groups to collaborate works and they are given training on income generating techniques.

One of their noted project was the Health Education and Livelihood Support Program for the Ultra Poor ( HELP UP) focusing on the three Upazillas of Rangpoor ${ }^{8}$, the most poverty stricken district of Bangladesh. The beneficiaries were divided into 840 groups considering their specific interest in IGAs. These beneficiaries were instructed and trained well so that within a few years the income of people reached to 4,919 BDT from 1.109 which is 4.4 times higher. ${ }^{9}$

The Christian Commission for Development in Bangladesh (CCDB) was founded in 1973 aiming to seek justice for sustainable livelihood for the poor and marginalized people in Bangladesh. Earlier, the focus of CCDB was relief and humanitarian activities which later on shifted to development activities for the poor and the ultra-poor.

One of the major poverty reduction programs of CCDB was the Comprehensive Poverty Reduction Program (CPRP) which aimed at reducing poverty along with few development objectives like women empowerment, food security, sustainable livelihood etc. Through this CPRP project, CCDB facilitates the beneficiaries with training and resources on agriculture, horticulture, fisheries, animal husbandry, and aquaculture and seed production. This commission is unique is in its attitude of reliance towards the beneficiary groups. ${ }^{10}$

\subsection{Health and Nutrition:}

Child Health and Nutrition has always been a great challenge for a developing country like Bangladesh. In spite of various difficulties, Bangladesh has made a significant progress in Child Health and nutrition areas. Along with the government, some Faith based NGOs are working in this area.

World Vision (WV), an international Christian relief organization aiming to serve vulnerable children and mother, has been working in Bangladesh since 1972. It has relief and rehabilitation program following the Christian ideology of serving people as the oppressed are the demonstration of unconditional love of God. ${ }^{11}$ At present, WVB is running at least eighty four program locations which is somehow connected with an estimated five million people from thirty five districts of Bangladesh. About one million children have been taken care of by their programs. The Programs of WVB cover mainly eight areas: AIDS, Maternal and Child Health, education, Food, Humanitarian affairs, Economic Development, women Empowerment, Child Rights and Institutional Capacity Development. ${ }^{12} \mathrm{WVB}$ is running their nutrition project in 66 Area Development Programs following WVB's nutrition intervention strategies. According to WVB, in 2013 they could reach to 41,245 children aged 6-35 months and it was found that $84 \%$ of the children have gained the necessary weight after just thirty days and severe malnutrition was reduced to $8 \%$ from approximately $27 \% .13$

Lutheran Aid to Medicine in Bangladesh is an intensive development project regarding rural health of the World Mission Prayer League aiming to serve God through serving people who are underprivileged and poor. They have special attention to women and children. This project covers $4-5$ million people under their medical facilities having a 115 bed hospital (1983) at Parbatipur, few community health programs and clinical services. This LAMB has successfully established 28 health care centers constituting 18 Safe Delivery Units (SDUs). These SDUs have 60 efficient birth attendants, 200 community health workers and 450 village health volunteers. Right now, LAMB is working with the Bangladesh government to set up 45 government family welfare centers for safe delivery and more than five hundred community clinics for primary health care services. ${ }^{14}$

\subsection{Peace building Initiatives and Interfaith Harmony:}

It is well known to all that Bangladesh is a peace loving country. ${ }^{15}$ But there is still a threat of conflicts. Conflicts can be originated from various types which are the direct hindrances on the way of development. Religion is a vital issue regarding peace and conflict. It has twofold aspects regarding creating conflict and regarding peace building. 16 There are many organizations which are working to establish peace through interfaith harmony. Along with the many INGOs, there are domestic NGOs and Academics who are trying to set a model of interfaith harmony.

Ramakrishna Mission was established in 1897 by swami Vivekananda, an influential spiritual leader of the Hindus after the name of Sri Ramakrishna who was the teacher of Vivekananda. Sri Ramakrishna believed that all the religions are true and all have a same destination. The epoch making speech of Vivekananda in Chicago in 1893 at the Parliament of world Religions is considered the first step towards interfaith movement.17

Ramakrishna Mission aims at character building and spiritual development of human being. One of their principal missions is to establish inter religious harmony. They usually arrange interfaith understanding gathering so that one can know other.18

Mennonite central committee is a development wing of the Mennonite Church aiming to share the love of God in the name of the Christ by providing human needs and working for the promotion of peace.19 As the Mennonite church is globally regarded as a peace-loving, they are well known for their pacifism and endeavor to establish peace. MCC along with another organization of France Brothers of Taize started peacebuilding project in 2007.20 Their headquarter is " The House of Peace" in Mymensingh . Members of " The shanty Mitra" or "Friends of peace", project name of MCC and BT meet once in a month to plan for peace motions and future work.21 MCC actively works to accommodate peace building process and conflict resolution strategies simultaneously across.

Blue Eyes Intelligence Engineering \& Sciences Publication (C) Copyright: All rights reserved. 
The country by providing training and awareness campaigns. In 2014, MCC established a peace building organization named "Payara" to extend their peace building activities in Bangladesh. ${ }^{22}$

Caritas Bangladesh has been working in the promotion of peace since Holy Cross father Richard 'Dick Timm's pioneering work establishing the justice and Peace Commission in the aftermath of the Bangladesh Liberation War. This program sought to build capability within the development communities for reconciliation efforts. Caritas started their The Justice and Peace (JPP) in 2002 aiming reconciliation in violent conflict zones and providing human rights education to the religious leaders from different faiths. This project has already reached to 52 districts covering 623 villages where by community teaching, people are instructed to resolute local conflicts. Caritas has special attention towards interfaith dialogue for consolidating interreligious harmony. ${ }^{23}$

\subsection{Educational Institutions in Developing Interfaith Harmony:}

In education sector Bangladesh has brought a significant change. The literacy rate is now about $70 \% .24$ Bangladesh government and many FIOs, INGOs and other organizations are providing education to millions of students.

\subsubsection{Secular Educational Institution:}

The Department of world Religions \& Culture, University of Dhaka was established in 1999 at the University of Dhaka by renowned professor Dr. Kazi Nurul Islam for the academic study of world religions and to promote interfaith harmony in country and overseas. ${ }^{25}$ This is the only one academic department in the Muslim world where all major and minor, living and dead religions are taught from historical, philosophical, anthropological, sociological and economic perspectives. This is not a mere the study of theology. This department has a center named Center for Interreligious and Intercultural Dialogue (CIID) which is working throughout Bangladesh to promote interfaith harmony among the people of different faiths. This center initiates research programs, seminars, field visits, international conferences focusing the need for interreligious harmony and methodology of establishing peace through religion and mutual respect. ${ }^{26}$

\subsubsection{Faith Based Academic Institutions and Interfaith Harmony:}

Haqqani Mission Bangladesh is the first organized Sufi Organization aiming towards social well being. ${ }^{27}$ Their principal focus is on peace through spiritual enlightenment and education. They believe that the delinking of moral and economic development in modern Bangladesh has led to a range of social ills including religious extremism and corruption. They try to concentrate on the true interpretation of Al-Quran. Haqqani Mission regards that misinterpretation of scripture often led people towards religious extremism. But interestingly this organized body has no paid workers like other NGOs, rather the member of this organization serve voluntarily. Haqqani Mission has special attention to formal and religious education. They established a Quran Research Center in 1993 and right now they are trying to establish an institute of Theology. ${ }^{28}$ Haqqani Mission is also trying to provide formal and vocational education through primary and secondary schools. They provide IT training facilities for making efficient personals in this sector. ${ }^{29}$

Dhaka Ahsania Mission was established by Khan Bahadur Ahsanullah aiming to extend education to the rural people.. He also played a major role in the establishment of the University of Dhaka which later on became the center place of the rise of Bengali nationalistic movements along with producing academics, researchers, leaders, bureaucrats and businessmen. This organization established many school and colleges like Khan Bahadur Ahsanullah Teachers' Training College and Ahsanullah University of science and Technology. They have 7,000 permanent office staffs who work in 172 Upazillas.30 They also work on people's hygiene and sanitation, microfinance, climate change and disaster risk management. By 71 different programs, they have reached to approximately six million people. DAM is conducting their education programs ranging from child education to adult education by its about 1900 The Children Learning Centers and other training institutions in rural areas. It is reported that they have provided primary and preprimary education to approximately thirty million children in six years along with a project of the European Commission.31 DAM also trains its teachers so that they can teach effectively. The motto of this Sufi based organization is providing humanitarian services to the poor. They also believe in common value system of all people because each and every religion speaks about common good. They also work in the promotion in the interreligious harmony.

Moanoghar and Banaphool Adibhasi green Heart College, Both institutions were established by Prajananda Mahathera who is a Theravada Buddhist from the Chakma community in the Chittagong Hill as and cultural background started to attend the college and within a few years it became a center of harmony in Chittagong Hill Tracts. Their focus is to provide basic needs of marginal people. They work to protect the cultural legacy of respective community along with social welfare programs. Moanghar has about 1500 primary, secondary and vocational students who receive almost free education. In 1990, Moanghar opened a school at Dhaka, funded by the European union in order to equip the indigenous people in urban and advanced world so that they can compete in the highly competitive world. Banophool has about 2000 students ranging from primary to college students.32 Both institutions, grounded in the Buddha's nonviolence attitude and humanitarian service are producing students who are working in top level in country and overseas. Moanghar is unique in its teaching students in five indigenous languages. This is regarded as a center for preserving indigenous culture of different groups. About 90 percent students of Banaphool are Muslims. Only 150 students are Buddhists. This is significant that though this was a faith inspired school and college rather people belonging to different religions are studying here.

\subsection{Faith Based Organizations on Climate Changes and Interfaith harmony:}

Bangladesh is among one of the few countries which is facing a constant threat of natural calamity and disaster due to a drastic climate change. ${ }^{33}$ Though Bangladesh is least responsible for this climate change but it has to face every possible natural calamities. In this field, many Faith based organizations have come forward to assist the government and to serve the people. Many of these faith based organizations have started working in Bangladesh from 1971.

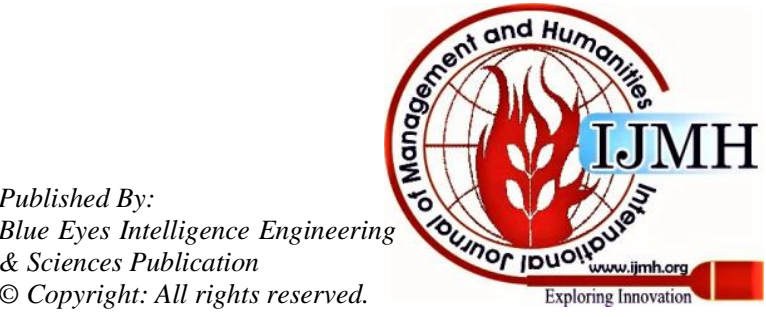


Church of Bangladesh is working on climate issues by its development wing The Church of Bangladesh Social Development Program (CBSDP) aiming to provide services to the costal people. It started to work unofficially in 1971 and registered as NGO in 1983.

It has five principal areas to focus: Resilient Livelihood and Food security, Disaster and Climate Change, Gender Justice and Women Empowerment, Social Security and Humanitarian services and Community Health Programs. ${ }^{34}$ The activities of this organization are community based and largely depend on people's participation.

The Christian Commission for Development in Bangladesh (CCDB) has special attention in climate change issues. They are giving training on disaster management to their staffs and others. Now they are also trying to set up a Climate Unit within its organizational framework which will facilitate CCDB staffs and common people through training, research and adaption policy. They are planning to set a Climate Solution Technology Park in Gazipur focusing on action oriented research for climate change adaption strategy.

\section{RELIGION AND DEVELOPMENT: PROGRESS AND HINDRANCE}

Further research is needed to understand the boost relationship between religion and development from a broader perspective. Religion, being a development issue is also hindrance on the way of development. For instance, there are many areas in Bangladesh where women are not permitted to work outside. There are many families which do not permit their daughters to go to secondary school or colleges.

Though they have a significant contribution in the development sector in Bangladesh, yet some FIOs have been accused of financing Islamic terrorist groups. For instance, Masjid Council for Community Advancement (MACCA), a faith based organization aiming to work on the poverty reduction was founded by Maolana Abul Kalam Azad, a leader of Bangladesh Jamat I Islami. ${ }^{35}$ Azad was sentenced to death on the charge of murder, rape and genocide in the liberation war of Bangladesh by the International Crime Tribunal, Bangladesh. His organization is said to fund some Islamic Terrorist Organizations in Bangladesh.

\section{CONCLUSION:}

Religion has been playing a key role in the development sector of around the world ${ }^{40}$. Crisis like Covid- $19^{41}$ has also called for inclusive development where every stake holders should act responsively. So, the development must be viewed from socio economic impact on the people. Sometimes the process may be slow but effective. Though few faith based organizations are alleged with financing the terrorists and proselytization; i.e. religious conversion, yet most of the Faith Inspired Organizations have made a significant contribution in poverty reduction, spreading education, facilitation health care, providing food facilities, raising awareness on population control, women's right and in many other sectors. Another important understanding is that FBOs can work upholding the true secular ${ }^{42}$ spirit of Bangladesh and against radicalization ${ }^{43}$. Though Bangladesh is a Muslim majority county, yet non-Muslim NGOs are working independently in Bangladesh. It is also evident that in many cases, religion based organizations cannot contribute much in development organizations due to the lack of firsthand knowledge of development and sometimes they do not have contact with the mainstream development organizations. Faith Inspired Organizations can be more effective if they work in collaboration with local people, traditional development NGOs and the government. But a special importance should be given on the engagement of religious leaders in this development work so that they can contribute in their respective areas more.

\section{End Notes}

1. Tomalin, E. 2013. Religions and Development. London: Routledge.

2. Barder, Owen, A Development policy for the $21^{\text {st }}$ century. available at https://www.cgdev.org/blog/development-policy-21st-century. Last accessed 12 January 2020.

3. Clarke, G. 2008. Faith Based Organizations and International Development: An overview. In: Clarke, G. and Jennings, M. ed. Development, Civil Society and faith Based Organizations: Bridging the sacred and the Secular. London: Palgrave Macmillan. pp. 17-45

4. ADB.2020. available

(https://www.adb.org/countries/bangladesh/poverty); Adams, Nathaniel \& Stark, Alexandra, Faith and Development in Focus: Bangladesh, 2015, The Berkley Center for Religion, Peace, and World Affairs at Georgetown University

a. (The authors of this article have used many links from this research work. To the best of knowledge of the author, this research work was done on the basis of intensive research work from field analysis. Before this research there was no rigorous research on religion and development in Bangladesh.)

5. Bangladesh Economic Review, 2015

6. Benthall and Bellion-Jourdan.2009. The Charitable crescent: The politics of Aid in the Muslim World. London: I.B. Tauris and Co Ltd.

7. Ibid

8. http://bdnews24.com/economy/2015/01/23/bangladesh-poverty-rate-h as-dropped-to-24.7-says-government-minister, Retrieved 27 November, 2015.

9. “Islamic Relief Worldwide Bangladesh.” Islamic Relief Bangladesh. http://irwbd.org/aboutus/irwb. Retrieved November 21, 2015

10. "Current Projects." Islamic Relief Worldwide Bangladesh. http://irwbd.org/projects/currentprojects. Retrieved November 23, 2015.

11. Ibid.

12. http://irwbd.org/projects/currentprojects. Retrieved November 24, 2015

13. Welcome to CCDB." Christian Commission for Development in Bangladesh (CCDB). http://www.ccdb-bd.org, Retrieved November 23, 2015.

14. "Our History." World Vision. http://www.worldvision.org/about-us/our-history, $\quad$ Retrieved November 20, 2015.

15. "Bangladesh." World Vision International. http://www.wvi.org, Retrieved November 25, 2015.

16. “Annual Report 2013." World Vision Bangladesh, 2013. Available at: http://www.wvi.org/bangladesh/publication/annual-report-2013

17. Introduction: Lamb." LAMB. http://www.lambproject.org, Retrieved November 21, 2015

18. And "Overview of Programs: Lamb." LAMB http://www.lambproject.org, Retrieved November 24, 2015.

19. For details, see The Daily Star, June 27, 2015. Bangladesh was ranked the $3^{\text {rd }}$ most peaceful country in South Asia in World Peace Index 2015 published by the Institute and Economics for Peace.

20. Religion, in one hand can contribute to peace building through its teachings and attitudes. On the other hand, violence is created in the name of religion which sometimes encompasses the entire world through a chain political process.

21. Adams, Nathaniel \& Stark, Alexandra, Faith and Development in Focus: Bangladesh, p.61.

22. Ibid., p.62.

23. "Mennonite Central Committee U.S." Mennonite Central Committee http://mcc.org, Retrieved November 22, 2015.

24. Adams, Nathaniel \& Stark, Alexandra, Faith and Development in Focus: Bangladesh, p.62.

25. Ibid, p.63.

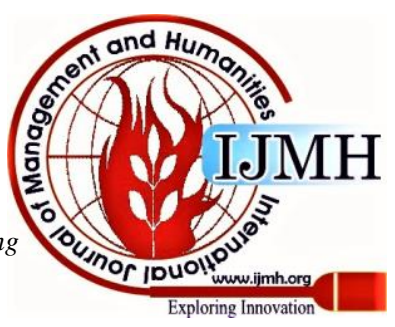


26. “Annual Fair for Peace and Harmony 2014." Caritas Bangladesh, $2014 . \quad$ http://www.caritasbd.org http://bdnews24.com/bangladesh/2015/06/16/bangladeshs-literacy-rat e-rises-to-70-percent-education-minister-says, Retrieved November $27,2015$.

27. Department of World Religions and Culture, www.du.org.bd

28. Department of World Religions and Culture, www.du.org.bd

29. Adams, Nathaniel \& Stark, Alexandra, Faith and Development in Focus: Bangladesh, p.66.

30. Ibid., 66 .

31. "About Us." Dhaka Ahsania Mission http://www.ahsaniamission.org.bd, Retrieved November 25, 2015.

32. Dhaka Ahsania Mission Children's Learning Centers (DAM-CLC)." Dhaka Ahsania Mission. http://www.ahsaniamission.org.bd, Retrieved November 25, 2015.

33. Vision and Mission." Moanoghar. http://www.moanoghar.org

34. Adams, Nathaniel \& Stark, Alexandra, Faith and Development in Focus: Bangladesh, p.71.

35. Ibid., p. 57.

36. Kumar, Anand, Islamic NGOs Funding Terror in Bangladesh, available www.mombu.com/culture/Bangladesh/t-Islamic-ngos-funding-terror, Retrieved November 26, 2015.

37. Kumar, A. 2009. Terror Financing in Bangladesh. Strategic Analysis. 33(6). Pp.903-917. DOI: 10.1080/09700160903255913

38. Islam, MD. 2021. The Role of Faith Based Organizations in Development: A Critical Analysis. Philosophy and Progress. (forthcoming)

39. Siddika, A. and Islam, MD. 2020. Covid-19 and Bangladesh: A study of the public perception on the measures taken by the government. EdArXiv.

40. Islam, MD and Huda, F. 2016. Religion and Politics: Bangladesh Perspectives. International Journal of Management and Humanities (IJMH). 2(4)

41. Islam, MD. And Siddika, A. 2020. Exploring the causes of religious extremism in Bangladesh: A critical analysis. The Dhaka University Studies. Vol-72-72, No- 1-2

\section{AUTHOR PROFILE}

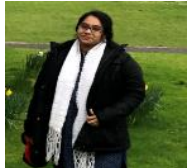

Ayesha Siddika, is a Lecturer at the Department of World Religions and Culture, University of Dhaka. Her research focuses on the interplay betwéen religion and politics, humanitarian crisis, refugee, and development issues. 